\title{
Exploring Factors Affecting Indonesian EFL Students' Reading Skill through Extensive Reading Activities
}

\author{
Salamuddin Selian', Nazriani Lubis², Yusnita ${ }^{3}$, Revi Restu Ayanda ${ }^{4}$ \\ ${ }^{1,4}$ Department of Magister of English Language Education, ${ }^{2,3}$ Department of English Language Education, \\ Univeristas Muslim Nusantara Al Washliyah, Medan, Indonesia. \\ Corresponding Author: Nazriani Lubis
}

DOI: https://doi.org/10.52403/ijrr.20220176

\begin{abstract}
Extensive reading in EFL context has the impact with English language skills, and language subskills; vocabulary mastery, reading speed rate. This research is conducted by applying This research is applied quantitative research method with ADDIE model in order to achieve the goal of increasing interest and understanding in reading English texts. The research location is in Faculty of Teacher Training and Education Universitas Muslim Nusantara (UMN) Al Washliyah, Medan, North Sumatera. In this research, questionnaire with Likert scale is used to help assess students' reading habits and critical thinking skills. According to the research result, Indonesian EFL students find the difficulties to improve reading skill, and the students also believe that ER activities will be the solution in to achieve English skill level. ER activities absolutely concern with the reading frequency, vocabulary mastery, prior knowledge, and higher order thinking. HOTs in ER activities will be more achievable because they way students understand English texts through enjoyable reading materials can be interpreted and evaluated.
\end{abstract}

Keywords: EFL students, extensive reading, reading enjoyment

\section{INTRODUCTION}

The issues of Extensive Reading or ER technique in EFL context have been discussed in order to create English students' reading behaviour and enjoyment (Bryan 2013; Nhapulo et all ,2017; Rodrigo et all, 2007). A study conducted by Li et all (2021) reports that EFL students' reading outcomes is being higher through implementing extensive reading skill in which the students significantly completed the books during the number of days. The result of the research discussed by Sun (2021) revealed that extensive reading technique integrated with differentiated instruction becomes a very helpful for the students to control and to manage their online learning by reading the book they read during pandemic covid 19. Moreover, the use of ER also leads to English teachers' perception that they totally agree with ER bringing much benefits, building up students and teachers' attitude, and it also increases the students to read extensively without worrying about the score (Huang, 2015). In Japan, EFL students find out the enjoyment in class readers where they can not only read the books chosen but they also have the opportunity to share with their classmates for checking their comprehension (Ramonda, 2020). Research conducted by Turnbul (2015) shows that L2 reading comprehension should be combined with group discussion in language learning which the students can use both their L1 and L2 in comprehending and producing the English text. Another empirical studies reports that ER technique is feasible and desirable, in which it can improve EFL students' reading rate and speed, and it makes EFL students' 
self-confidence and motivation being higher since they are no longer need teachers' guidance (Chang, 2010; Nhapulo et all, 2017). Since decade ago, several empirical studies have been conducted to reveal the positive effect of extensive reading (ER) in which ER also lead to the wider range of L2 skills, and L2 behavior, namely; reading comprehension (Bell, 2001; Hafiz \& Tudor, 1989; Leung, 2002; Nakanishi \& Ueda, 2011; Yamashita, 2008), reading fluency (Iwahori, 2008), reading strategies or skills (Hayashi, 1999; Hitosugi \& Day, 2004), writing (Hafiz \& Tudor, 1989; Mason \& Krashen, 1997), linguistic knowledge (Hedge, 1985; Yang, 2001) and positive attitudes (Constinito, 1995; Yamashita, 2013). It is commonly known that the only way to do the EFL learners to acquire the English skills is receiving numerous English written texts through reading activities. Reading activities become extremely vital for EFL learners since they have much opportunities to acquire new words, new expression, and the way sentences constructed. In order to enhance students' reading skill, the implementation of extensive reading will be very helpful, and it results a very significant effect.

\section{LITERATURE REVIEW}

The impact of reading activities directly develop English development of EFL students, several empirical studies have been conducted to reveal the positive effect of extensive reading (ER) because ER leads to the wider range of L2 skills, and L2 behavior, namely; reading comprehension (Bell, 2001; Hafiz \& Tudor, 1989; Leung, 2002; Nakanishi \& Ueda, 2011; Yamashita, 2008), reading fluency (Iwahori, 2008), reading strategies or skills (Hayashi, 1999; Hitosugi \& Day, 2004), writing (Hafiz \& Tudor, 1989; Mason \& Krashen, 1997), linguistic knowledge (Hedge, 1985; Yang, 2001) and positive attitudes (Constinito, 1995; Yamashita, 2013). One of the recommended reading activities is Extensive Reading, it is also well-recognized as ER. ER is a reading technique consisting of activity to read a lot of easy level text reading (Suk, 2017).

In order to achieve the purpose of reading, students are given the freedom to choose the books they like so that they have chance to read a large number of vocabularies, find English expressions in which all these activities can improve reading comprehension and interest. In addition, the higher reading frequency not only increases vocabulary but also increases knowledge, and self-confidence (BR et all 2020). Continuously, the regular activities performed by EFL students will shape their background knowledge so that every material/book/article they read will be easier to understand because the students have stored previous knowledge in their schemata (Muliyani, 2017).

Absolutely, it will make EFL students easier to convey ideas because they have relevant information, so that their arguments become sharper. In other words, Extensive Reading activities touch many aspects such as; learning process, students' needs, and the availability/opportunities in the classroom (Kustina, 2018; Ikhsanuddin, 2018; Putra, 2019). ER activities is created based on four elements namely; a large number of reading materials, easy materials, faster reading rate, and reading enjoyment (Lubis, 2019; Yamashita, 2015).

The input hypothesis of Krashen has been using by ER procedures in which the essential point of is "students learn to read by reading" (Smith, 2006). English learners are required to own reading fluency through achieving large number of vocabularies so that English learners automatically improve a higher reading speed (Bell, 2001; Day \& Bamford, 2002; Prawiyata, 2020; Taguchi, Takayasu-Maass, \& Gorsuch, 2004). Rott, 1999; Silva, 2009). Through ER technique, the students' ER speed will be leveling up higher than conventional reading technique (Day \& Bamford, 2002), and it also leads to the way the interpret through academic writing (Lubis, 2021) 
Day and Bamford (1998) suggested ten principles of applying ER programs, namely;

(1) the reading material is easy, (2) A variety of reading material on a wide range of topics must be available, (3) learners choose what they want to read, (4) earners read as much as possible, (5) the purpose of reading is usually related to pleasure, information and general understanding, (6) reading is its own reward, (7) reading speed is usually faster rather than slower, (8) reading is individual and silent, (9) teachers orient and guide their students, (10) the teacher is a role model of a reader (Day 2002, 137-139; Hitosugi and Day 2004, 2122)

\section{MATERIALS \& METHODS}

This research is applied quantitative research method with ADDIE model in order to achieve the goal of increasing interest and understanding in reading English texts. The research location is in Faculty of Teacher Training and Education Universitas Muslim Nusantara (UMN) Al Washliyah, Medan, North Sumatera. The population is a generalization area consisting of subjects that have the qualities and characteristics set by the researcher to be studied and conclusions drawn or in other words all components that exist in the research place. The population in this study were all classes of FKIP UMN AW. Then, 60 students of the English Education Study Program were recruited using a nonprobability sampling technique and determined by purposive sampling based on certain considerations. In this case, quantitative research explains that quantitative research instruments are used to measure the variables to be studied and to measure the phenomena being observed, in the hope of completing the data. Student scores will use predetermined assessment indicators and descriptors. The instrument used is a project-based learning process for scientific writing with citations, and proper paraphrasing with digital tools

\section{Data Collection Techniques}

To obtain precise and correct data, the researchers will use data collection techniques, as follows:

a. Questionnaire

In this study, to help assess students' reading habits and critical thinking skills, students were given a Likert scale questionnaire.

According to Sugiyono (2010:142) a questionnaire is a data collection technique that is carried out by providing written statements to respondents. With the aim of knowing in more detail to know the analysis of the situation through the data.

\section{b. Observation}

The observation applied was participatory observation, where the appropriate observation used was participatory observation. Participatory observation by involving researchers (as direct observers) and students in daily activities both in class and in the environment

\section{Data Analysis Techniques}

In accordance with the data collection techniques that have been carried out, the data processing procedure is carried out through a number of stages, namely:

a. Checking student observation sheets based on predetermined assessment aspects

b. Give a score on the aspects that are examined in accordance with the predetermined scoring provisions, then the score obtained by each student is calculated as a value which is then tested by testing factor analysis (KMO)

c. Recap the assessment data obtained by students for each aspect studied.

d. Summing up the scores obtained by students in each aspect studied, then looking for the average value.

\section{RESULT}

\section{Research Results}

Based on the data recapitulation of the difficulty factor in reading English texts 
for students in semester II, IV, and VI of English Education, the results of this study indicate that there are several main factors that cause students' low interest in reading, and it has the impact on higher-order thinking skills.

\section{Recapitulation of Reading Difficulty Factors}

To reveal the factors of difficulty in reading English texts faced by English
Language Education students, the questionnaire was distributed online using a google form based on four indicators used as parameters, namely; frequency, prior knowledge, vocabulary mastery, and higher order thinking (HOTs). In detail, the results of the recapitulation are shown in diagram 5.1

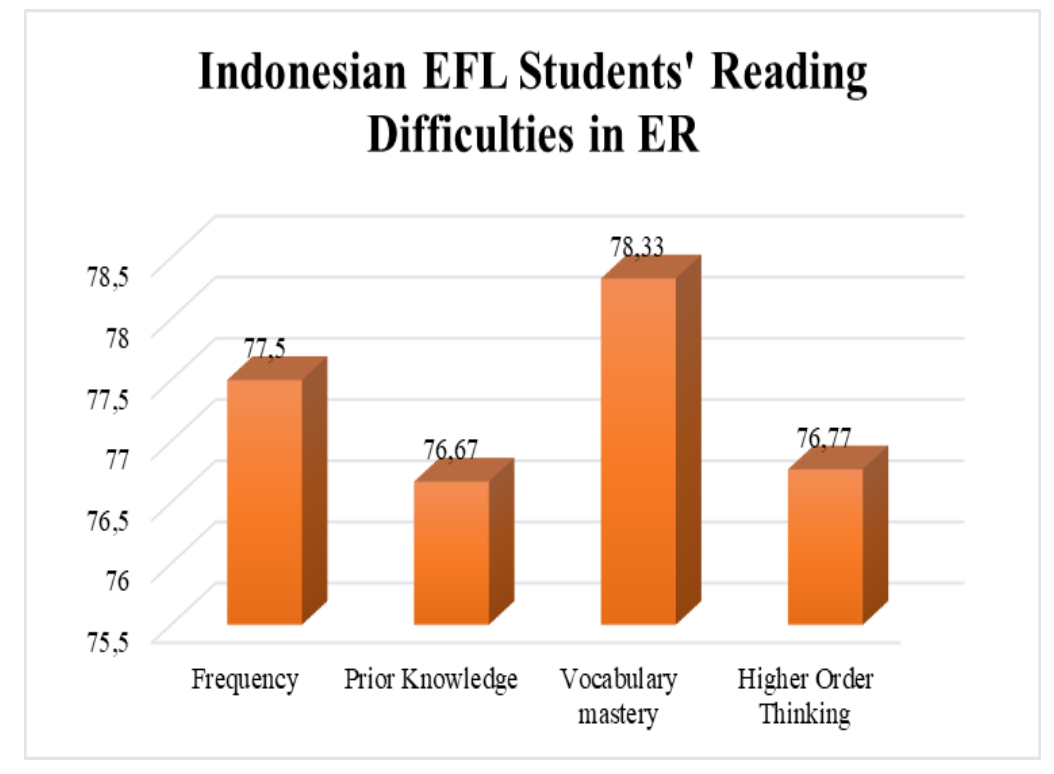

Based on diagram 5.1, the factors of reading difficulties experienced by students are; frequency with $77.5 \%$, prior knowledge with $76.67 \%$, vocabulary mastery with $78.33 \%$, and HOTs with $76.77 \%$. This shows that students still have difficulty in reading due to their low vocabulary. Then, the frequency indicator becomes a difficulty that is still faced by students. Simultaneously, prior knowledge and higher order thinking. It is a factor that is still a problem for students. Of course, students have low interest in reading, this can be seen from the relationship of each indicator. The frequency of reading that is rarely done causes students to have very little input so that their vocabulary is low. Along with this, it will cause difficulties for students to have prior knowledge, because it cannot be denied that one of the successes in reading comprehension can be achieved if the reader has good prior knowledge. Good prior knowledge will help the reader build, or understand new knowledge from new reading sources. In other words, prior knowledge is the background of knowledge or previous knowledge possessed by the reader on a particular topic.

\section{HOTs Factors Found in ER Activities}

To investigate the role of HOTs in reading, there are two indicators used as parameters, namely; interpreting, and evaluating. Interpreting skill is needed in reading comprehension because reading is a very complex cognitive process where readers need high-level thinking to understand, capture meaning in depth and intact without reducing the meaning content. To reveal the results of the recapitulation of Hots' difficulty factor in reading, diagram 5.2 visually displays the data recapitulation; 

reading activities.

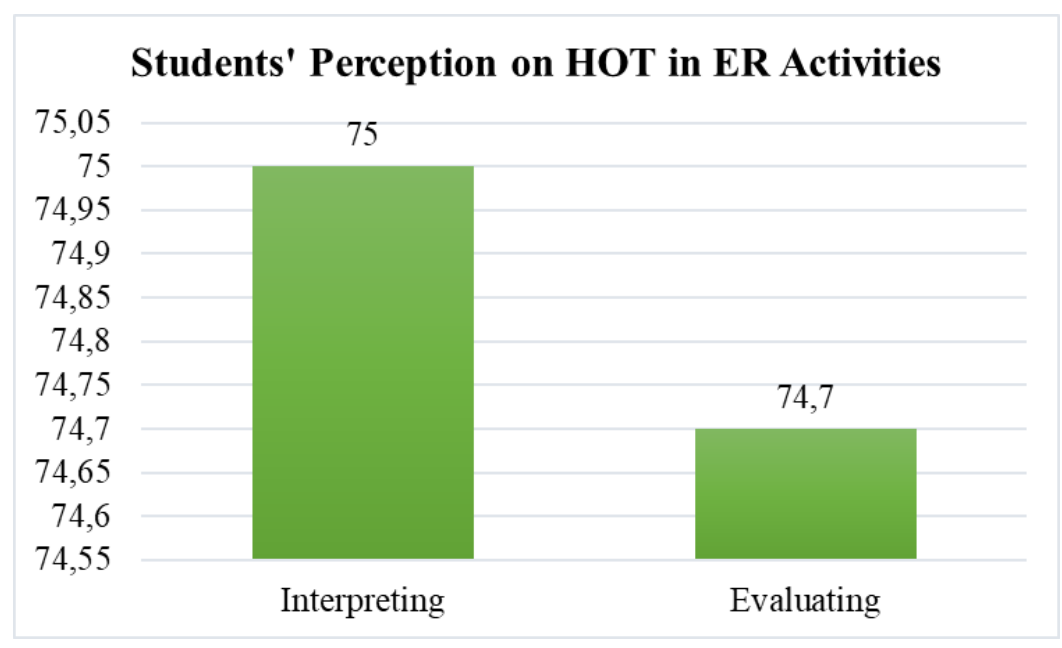

In detail, diagram 5.2 shows that students have difficulty in improving their reading skills. It is proven that $75 \%$ of students say that they have difficulty in interpreting information from reading texts, and of course this affects them to do critical reading, namely evaluating. In fact, the ability to interpret and evaluate has reached the domain of higher-order thinking.

\section{Formulation of the Concept of Extensive Reading Activities that are integrated with HOTS to Increase Interest and Reading Comprehension}

Based on the results of data recapitulation, it can be seen that students still need solutions in reading comprehension. Reading comprehension can begin with extensive reading. Extensive Reading is related to reading books/texts that we like. In this case, the extensive reading approach focuses more on the reading material you enjoy, and how to enjoy the reading. In other words, students are trained to get used to reading their favorite books on a regular basis every day. Then, students are given feedback, so that gradually students have a higher reading frequency and, it will lead to an increase in vocabulary, prior knowledge, and behavior. So, it will be easily integrated with higher order thinking.

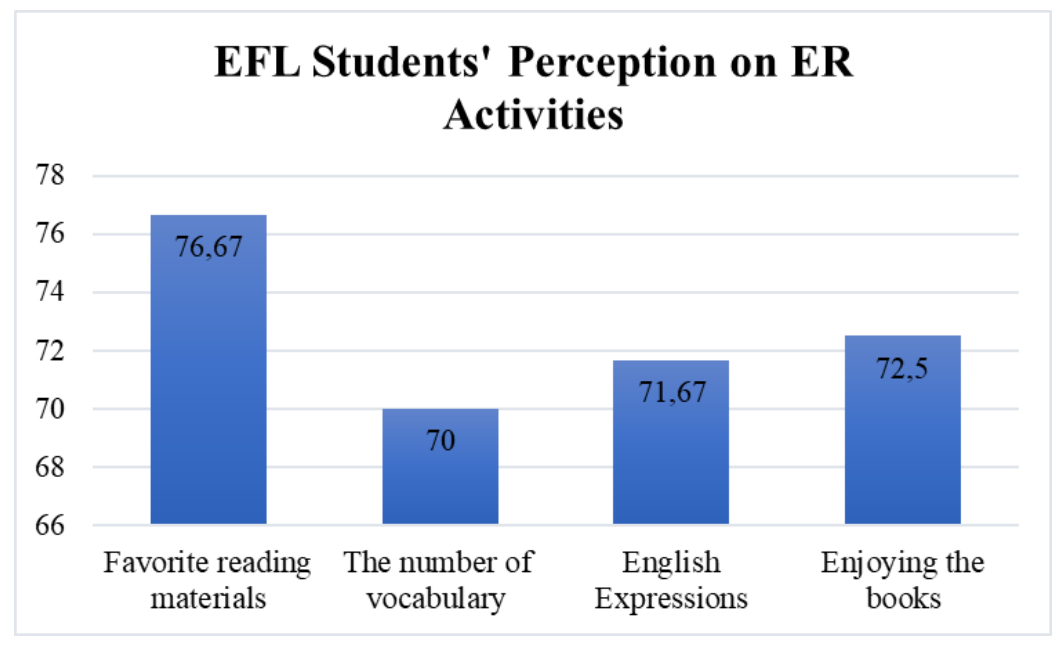

According to the research result, Indonesian EFL students find the difficulties to improve reading skill, and the students also believe that ER activities will be the solution in to achieve English skill level. ER activities absolutely concern with the reading frequency, vocabulary mastery, prior knowledge, and higher order thinking. HOTs in ER activities will be more achievable because they way students 
understand English texts through enjoyable reading materials can be interpreted and evaluated. Moreover, reading activities lead the students to find out the desire to read (Krashen, 2004), however the students' interest in reading is always linked to the motivation in which the student will be more challenging with the difficult reading materials (Schunk and Zimmerman 1997), so that English teachers are suggested to select reading task and activities (Gardner and Lambert 1972; Lifrieri 2005).

\section{CONCLUSION}

Based on the research results, this study concludes that there are four factors of low reading comprehension, namely; frequency, vocabulary mastery, prior knowledge, and HOTs. In addition, the difficulty of reading that is owned by students affects the weakness of higherorder thinking skills which can be seen from two main factors, namely; interpret, and evaluate. All indicators of reading difficulty factors are integrated with each other, which causes students' low interest and reading comprehension. To overcome this, further research will design a prototype of extensive reading activity. Extensive reading activities are very focused on fostering a love of reading with a focus on bringing the books you like and how to enjoy the books/texts you read. To achieve the research objectives comprehensively, the researcher suggests several points, namely: English education students find their favorite reading material to improve their reading comprehension of English texts, and the researchers designed a prototype of extensive reading activity. Extensive reading activities are very focused on fostering a love of reading with a focus on bringing the books you like and how to enjoy the books/texts you read.

\section{Acknowledgement: None}

Conflict of Interest: None

Source of Funding: None

\section{REFERENCES}

1. Abdelhalim, S. M. (2017). Developing EFL students' reading comprehension and reading engagement: Effects of a proposed instructional strategy. Theory and Practice in Language Studies, 7(1), 37-48.

2. Adam, Norhaslina, and Adibah Abdul Latif. "Students' Ability in Answering Higher Order Thinking Skills (HOTS) Questions in Islamic Education Subject." Advanced Science Letters 24.1 (2018): 479-481.

3. Ashadi, Rido Imam, and Nazriani Lubis. "A Survey on the Levels of Questioning of ELT: A Case Study in an Indonesian Tertiary Education." Advances in Language and Literary Studies 8.3 (2017): 26-31.

4. Bell, T. (2001). Extensive reading: Speed and comprehension. The reading matrix, 1(1).

5. BR, M. J. M., Myranda, V. R., \& Sugiyono, S. A. (2020, September). Program Membaca Ekstensif: Penggunaan Artikel dari Berbagai Media Meningkatkan Pengetahuan, Keterampilan Bahasa Inggris, dan Percaya Diri. In Prosiding Industrial Research Workshop and National Seminar (Vol. 11, No. 1, pp. 1200-1206).

6. Chen, Chun-cheng, Ming-chang $\mathrm{Wu}$, and Ting-ting $\mathrm{Wu}$. "Discussion on the Teaching and Learning Innovation of Higher-Order Thinking." International Conference on Innovative Technologies and Learning. Springer, Cham, 2018.

7. Constantino, R. (1995). Learning to read in a second language doesn't have to hurt: The effect of pleasure reading. Journal of Adolescent \& Adult Literacy, 39(1), 6869.

8. Day, R., \& Bamford, J. (2002). Top ten principles for teaching extensive reading. Reading in a Foreign Language, 14, 136_141.

9. Hafiz, F. M., \& Tudor, I. (1989). Extensive reading and the development of language skills. ELT journal, 43(1), 4-13.

10. Hayashi, K. (1999). Reading strategies and extensive reading in EFL classes. RELC journal, 30(2), 114-132. 
11. Hitosugi, C. I., \& Day, R. R. (2004). Extensive reading in Japanese. Reading in a foreign language, 16(1), 20-30.

12. Hitosugi, C. I., \& Day, R. R. (2004). Extensive reading in Japanese. Reading in a foreign language, 16(1), 20-30.

13. Iwahori, Y. (2008). Developing reading fluency: A study of extensive reading in EFL.

14. Leung, C. Y. (2002). Extensive reading and language learning: A diary study of a beginning learner of Japanese.

15. Li, H., Majumdar, R., Chen, M. R. A., Yang, Y., \& Ogata, H. (2021). Analysis of self-directed learning ability, reading outcomes, and personalized planning behavior for self-directed extensive reading. Interactive Learning Environments, 1-20.

16. Ikhsanudin, I., \& Suparjan, S. Buku Wisata Kalimantan Barat untuk Mendukung Kegiatan Membaca Ekstensif Bahasa Inggris di Universitas Tanjungpura. ICoTE Proceedings, 2(1), 33-38.

17. Kustina, R., \& Putri, U. T. (2018, October). Kemampuan menemukan ide pokok melalui membaca ekstensif dengan metode inquiri. In prosiding seminar nasional pendidikan dasar 2018. STKIP Bina Bangsa Getsempena.

18. Lubis, N., \& Lubis, A. (2019, April). Enhancing 21st Century Skill through Teaching Model Collaboration in Indonesian EFL Classroom. In 3rd Asian Education Symposium (AES 2018). Atlantis Press.

19. Lubis, N., Lubis, A., \& Irawani, P. O. (2021, August). Investigasi faktor yang mempengaruhi performasi tulisan ilmiah mahasiswa. In prosiding seminar nasional hasil penelitian (Vol. 4, No. 1, pp. 439443).

20. Muliyani, N. (2017). Pengaruh Skema Siswa dan Membaca Ekstensif dengan Hasil Belajar Bahasa Inggris Siswa. Faktor Jurnal Ilmiah Kependidikan, 4(1), 55-66.

21. Nhapulo, M. A., Simon, E., \& Van Herreweghe, M. (2017). Enhancing academic reading skills through extensive reading. Southern African Linguistics and Applied Language Studies, 35(1), 17-40.

22. Bryan, S. (2011). Extensive Reading, Narrow Reading and second language learners: implications for libraries. The Australian Library Journal, 60(2), 113122.

23. Prihantoro, Agung. "Kerangka Landasan Untuk Pembelajaran Dan Asesmen." (2010).

24. Prawiyata, Y. D. (2020). The Use Of Anagrams To Increase students' English vocabulary mastery. Jurnal penelitian pendidikan bahasa dan sastra, 5(1), 22-24.

25. Putra, D., Musthafa, B., \& Wirza, Y. Program Membaca Ekstensif: Meningkatkan Motivasi Membaca Siswa. Jurnal Penelitian Pendidikan, 19(3), 322333.

26. Ramonda, K. (2020). Extensive reading and class readers: the case for no choice. ELT Journal, 74(3), 277-286.

27. Rodrigo, V., Greenberg, D., Burke, V., Hall, R., Berry, A., Brinck, T., ... \& Oby, M. (2007). Implementing an extensive reading program and library for adult literacy learners.

28. Rott, S. (1999). The effect of exposure frequency on intermediate language learners' incidental

29. vocabulary acquisition and retention through reading. Studies in Second Language Acquisition,21(4), 589_619

30. Singh, Charanjit Kaur Swaran, et al. "Developing a Higher Order Thinking Skills Module for Weak ESL Learners." English Language Teaching 11. (2018): 86-100.

31. Smith, K. (2006). A comparison of "pure" extensive reading with intensive reading and extensive reading with supplementary activities. The International Journal of Foreign Language Teaching, 2(2), 12_15.

32. Sugiono., 2010. Metode Penelitian Pendidikan Pendekatan Kuantitatif, Kualitatif dan R\&D. Bandung. Penerbit Alfabeta

33. Suk, N. (2017). The effects of extensive reading on reading comprehension, reading rate, and vocabulary acquisition. Reading Research Quarterly, 52(1), 7389. 
34. Sun, Z., Yang, X. M., \& He, K. K. (2016). An extensive reading strategy to promote online writing for elementary students in the 1: 1 digital classroom. Computer Assisted Language Learning, 29(2), 398412.

35. Huang, Y. C. (2015). Why don't they do it? A study on the implementation of extensive reading in Taiwan. Cogent Education, 2(1), 1099187.

36. Taguchi, E., Takayasu-Maass, M., \& Gorsuch, G.J. (2004). Developing reading fluency in EFL:

37. How assisted repeated reading and extensive reading affect fluency development. Reading in a Foreign Language, 16(2), 70_96
38. Turnbull, B. A. (2015). The effects of L1 and L2 group discussions on L2 reading comprehension (Doctoral dissertation, University of Otago).

39. Yamashita, J. (2008). Extensive reading and development of different aspects of L2 proficiency. System, 36(4), 661-672.

How to cite this article: Salamuddin Selian, Nazriani Lubis, Yusnita et.al. Exploring factors affecting Indonesian EFL students' reading skill through extensive reading activities. International Journal of Research and Review. 2022; 9(1): 650-657. DOI: https://doi.org/10.52403/ijrr.20220176 